\title{
Composition of the Essential Oil of Endemic Salvia cryptantha (Lamiaceae) Montbret \& Aucher Ex Bentham from
}

\section{Türkiye'de Endemik Salvia cryptantha (Lamiaceae)'nın Montbret \& Aucher Ex Bentham Uçucu Yağ Kompozisyonu}

\author{
Research Article
}

Gülden Doğan', Şükrü Hayta², Azize Demirpolat', Eyüp Bağcı'

${ }^{1}$ Fırat University, Science Faculty, Biology Department, Elazı̆̆, Turkey.

${ }^{2}$ Bitlis Eren University, Art \& Science Faculty, Biology Department, Bitlis, Turkey.

\section{A B S TR AC T}

\begin{abstract}
n this study, the essential oil composition of Salvia cryptantha Montbret \& Aucher ex Bentham from Turkey. The qualitative and quantitative essential oil contents of the this species was determined and compared with each other. The chemical composition of essential oils obtained by hydrodistillation of Salvia cryptantha was investigated by GC and GC-MS. The essential oils yield is $0.4(\mathrm{v} / \mathrm{w})$. Sixty three constituents were comprised the $98.7 \%$ of the total essential oil extracted from the Salvia cryptantha. The predominant compounds of Salvia cryptantha were determined as 1.8 -cineole (21\%), camphor (19.1\%), $\alpha$-pinene $(12.5 \%)$, camphene $(8.7 \%)$.
\end{abstract}

\section{Key Words}

Salvia cryptantha, GC-MS, Essential Oil, 1.8-Cineole, Camphor.

\section{öz}

Q çalışmada, Türkiye için endemik Salvia cryptantha'nın Montbret \& Aucher ex Bentham uçucu yağ Bompozisyonu analiz edildi. Bu türün nicel ve nitel uçucu yağ içeriği belirlendi ve birbirleriyle karşılaştırıldı. Uçucu yağın kimyasal kompozisyonu su damıtımı yardımıyla belirlendi ve GC/GC-MS kullanılarak incelendi. Uçucu yağ verimi 0.4\% (v/w)'dir. Salvia cryptantha'tadan 63 bileşenin elde edilen toplam uçucu yağın \%98.7'sini oluşturduğu görüldü. Salvia cryptantha'da temel bileşenler 1.8-sineol (\%21), kafur (\%19.1), $\alpha$-pinen (\%12.5) ve kamfen (\%8.7) olarak belirlendi.

\section{Anahtar Kelimeler}

Salvia cryptantha, GC-MS, Uçucu Yağ, 1.8-Sineol, Kamfor.

Article History: Received: Mar 11, 2017; Revised: Aug 15, 2017; Accepted: Oct 25, 2017; Available Online: Dec 25, 2017. DOI: 10.15671/HJBC.2017.171

Correspondence to: G. Doğan, Firat University, Science Faculty, Biology Department, Elazig, Turkey. 


\section{INTRODUCTION}

Salvia L. is the largest genus of plants in the Lamiaceae family, with approximately 900 species including annual, biennial or perennial herbs, along with woody subshrubs [1]. The genus is distributed throughout the world with the center of diversity and origin appearing to be Central and Southwestern Asia [2]. An unusually large number of useful secondary metabolites belonging to various chemical groups, such as essential oils, terpenoid compounds, and phenolic derivatives, have been isolated from the genus, which features prominently in the pharmacopoeias of many countries throughout the world [3]. Salvia L. species which is represented by 95 species in total in Turkey [4]. Salvia cryptantha is represented in $\mathrm{C}$ group in Flora of Turkey. The species is endemic and Iran-Turan element. The wild growing species is endemic to the rocky lands and chalky hills of Turkey, widely distributed from 700 to $2500 \mathrm{~m}$ [5]. S. cryptantha is a perennial bush branching in a disorderly fashion on the ground. Its older branches are brittle and rough while the younger ones are soft and covered by fine fuzz. It flowers in May up to late August. S. cryptantha plants are generally propagated through cuttings [3]. Salvia crypthantha, named "tapir" in Turkish, is a plant growing wild in Middle Anatolia and its dried flowers are used as a herbal tea and local materia medica [6]. A less variable species than its close relative $S$. multicaulis and generally more western in its distribution. In areas where they overlap, e.g. Sivas and Niğde, they appear to retain their identity and no hybrids have been seen [5].

Salvia species have been recorded to be used for memory enhancement in European folk medicine [7] and have been also used as folk remedy in tea form against simple disordes in Anatolia [8]. Several species are used to treat microbial infections, cancer, malaria, inflammation, loss of memory and to disinfect homes after sickness [2]. In Turkish folk medicine, some Salvia species have been recorded to be used against wounds, inflammatory and skin diseases [9-11]. For instance; the roots of Salvia aethiopsis are boiled together with the resin of Abies bornmülleriana, butter, and basewax, the mixture is then condensed into an ointment form, which is applied every day on cuts and other wounds for 5-10 days. The aerial parts of Salvia tomentosa Mill. are used againist rheumatic pain. Salvia nemorosa is pounded and applied externally to stop bleedings and to heal wounds [12]. Infusion prepared with aerial parts of Salvia cryptantha is used for stomach disorders internally; the decoction obtained from aerial parts is used as antiseptic for wounds [11]. It is reported that the $S$. cryptantha has antitumoral potential aganist breast cancer [13].

Recently, the essential oils and various extracts of plants have provoked interest as sources of natural products. They have been screened for their potential uses as alternative remediesfor the treatment of many infectious diseases and the preservation of foods from the toxic effects of oxidants. Particularly, the antimicrobial activities of plant oils and extracts have formed the basis of many applications, including raw and processed food preservation, pharmaceuticals, alternative medicine and natural therapies $[14,15]$.

\section{MATERIALS and METHODS}

\section{Plant Material}

Salvia cryptantha specimens were collected during to flowering stage in June, 2011, at an altitude of 1330 m, Darende (Sivas-Turkey). Voucher specimens are kept at the Firat University Herbarium (FUH-9010). Air-dried aerial parts of the plant materials $(100 \mathrm{~g})$ were subjected to hydrodistillation using a Clevengertype apparatus for $3 \mathrm{~h}$ to yield. The essential oil was analyzed by using GC and GC-MS.

\section{Isolation of the Essential Oils}

Air-dried aerial parts of the plant materials (100 g) were subjected to hydrodistillation using a Clevenger-type apparatus for $3 \mathrm{~h}$.

\section{Gas Chromatographic (GC) Analysis}

The essential oil was analysed using HP 6890 GC equipped with FID detector and HP- 5 MS (30 m x $0.25 \mathrm{~mm}$ i.d., film tickness $0.25 \mu \mathrm{m}$ ) capillary column was used. The column and analysis conditions were the same as in GC-MS expressed as below. The percentage composition of the essential oils was computed from GC-FID peak areas without correction factors. 


\section{Gas Chromatography/Mass Spectrometry (GC-MS) Analysis}

The oils were analyzed by GC-MS, using a Hewlett Packard system. HP- Agilent $5973 \mathrm{~N}$ GC-MS system with 6890 GC in Plant Products and Biotechnology Res. Lab. (BUBAL) in Firat University. HP-5 MS column (30 m x 0.25 mm i.d. film tickness $0.25 \mu \mathrm{m}$ ) was used with helium as the carrier gas. Injector temperature was $250^{\circ} \mathrm{C}$ split flow was $1 \mathrm{ml} / \mathrm{min}$. The GC oven temperature was kept at $70^{\circ} \mathrm{C}$ for $2 \mathrm{~min}$. and programmed to $150^{\circ} \mathrm{C}$ at a rate of $10^{\circ} \mathrm{C} / \mathrm{min}$ and then kept constant at $150^{\circ} \mathrm{C}$ for $15 \mathrm{~min}$ to $240^{\circ} \mathrm{C}$ at a rate of $5^{\circ} \mathrm{C} / \mathrm{min}$. Alkanes were used as reference points in the calculation of relative retention indices (RRI). MS were taken at $70 \mathrm{eV}$ and a mass range of 35-425. Component identification was carried out using spectrometric electronic libraries (Wiley, Nist).

\section{RESULTS and DISCUSSIONS}

The chemical composition of essential oils obtained by hydrodistillation of Salvia cryptantha was investigated by GC and GC-MS. The essential oils yield is $0.4(\mathrm{v} / \mathrm{w})$. Sixty three constituents were comprised the $98.7 \%$ of the total essential oil extracted from the Salvia cryptantha. The predominant compounds of Salvia cryptantha were determined as 1,8-cineole (21\%), camphor $(19.1 \%), \alpha$-pinene $(12.5 \%)$, camphene $(8.7 \%)$ (Table 1). The oil was complex mixtures of nonterpenes, monoterpenes and sesquiterpenes: 63 components were identified in essential oil under study. The essential oil is mainly composed of monoterpene derivatives. The essential oil analysis showed that oxygenated monoterpenes and monoterpenes concentrations were higher than those of oxygenated sesquiterpenes and sesquiterpenes.

GC-MS analysis revealed that the major constituents of the S. cryptantha and S. multicaulis oils were $\alpha$-pinene (18.1 and 21.9\%), 1,8 cineole (eucalyptol) (15.3 and 20.1\%), camphor (7.7 and $11.0 \%)$, camphene (6.4 and 7.8\%) and borneol (4.8 and $7.3 \%$ ), respectively [16]. Our analysis results study were showed similarity with the Tepe's findings, because of the presence of the major components; 1,8 cineole (21\%), camphor (19.1\%), $\alpha$-pinene $(12.5 \%)$, camphene $(8.7 \%)$ in our sample.
1,8-Cineole (15.7-37.1\%), camphor (6.0-13.0\%), $\alpha$-pinene (1.0-11.9\%) and camphene (0.9-7.7\%) were found to be the major components in the S. crypthantha oils [17]. Bayrak and Akgül stated that oil of $S$. crypthantha contained borneol (24.8\%), camphor (17.5\%), 1,8-cineole (10.4\%) and $\alpha$-pinene (5.8\%) as major components [18]. It was reported that camphor (18.1\%), 1,8-cineole (17.8\%), bornyl acetate (11.4\%) and borneol (5.8\%) as the main components in S. crypthantha oil [19]. A survey of the literature reveals that oil of S. crypthantha was found to contain 1,8-cineole (27.9\%), bornyl acetate (17.1\%) and camphor (15.6\%) [20].

Saadia et al. [6] reported that oil of S. cryptantha contained camphor (25.6\%). 1,8-Cineole (20.3\%), $\beta$-pinene (12.8\%), $n$-hexane (10.6\%), borneol (5.1\%) and $\alpha$-pinene (4.1\%) were the other important components. The volatile fraction of the Turkish S. crypthantha differs from many Salvia species growing in the Mediterranean region, in regards to compounds, in the variety of its components and their relative quantity [6].

The contents of essential oil were obtained $1.44 \%$ in aerial part and $0.4 \%$ in flower. Thirteen components in aerial parts oil and 10 components in flower oil were identified, representing 97.89 and $97.33 \%$, respectively. 1,8 -Cineole (30.38 and $36.28 \%$ ), valencene (24.34 and $26.53 \%$ ) and camphor (12.29 and $14.72 \%$ ) were found as the major components of both aerial parts and flower oils, respectively [21].

The essential oil composition of the Salvia trichoclada and S. multicaulis- belongs to the same group B in genus Salvia from Turkey; 1,8-cineole (17.0\%), camphor (13.2\%), $\alpha$-pinene (9.3\%), valeranone (8.5\%) and $\alpha$-eudesmol (5.7\%) were determined to be present at a high compounds of the S. multicaulis oil and $\beta$-pinene (13.7\%), camphor $(11.3 \%)$, caryophyllene oxide $(7.0 \%)$, 1,8-cineole (5.9\%) and trans-caryophyllene (5.5\%) were in S. trichoclada essential oil [22]. Another our study essential oil composition of $S$. palaestina and $S$. tomentosa the major components $\beta$-caryophyllene (18\%), germacrene D (16.5\%), linalool L (9.2\%), caryophyllene oxide (7.3\%), linalyl acetat (6\%), $\alpha$-copaene (4.3\%), 
318 | G. Doğan et al. / Hacettepe J. Biol. \& Chem., 2017, 45 (3), 315-320

Table 1. Constituents of the essential oil from S. crypthantha.

\begin{tabular}{|c|c|c|c|}
\hline No & Compounds & RRI & $\%$ \\
\hline 1 & Hexanal & 936 & 0.1 \\
\hline 2 & Tricyclene & 1014 & 0.4 \\
\hline 3 & $\alpha$-Thujone & 1016 & 0.3 \\
\hline 4 & $\alpha$-Pinene & 1021 & 12.5 \\
\hline 5 & Camphene & 1035 & 8.7 \\
\hline 6 & Sabinene & 1052 & 0.4 \\
\hline 7 & $\beta$-Pinene & 1056 & 4.6 \\
\hline 8 & 3-Octanone & 1061 & 0.1 \\
\hline 9 & $\beta$-Myrcene & 1064 & 1.3 \\
\hline 10 & $\alpha$-Terpinene & 1085 & 0.1 \\
\hline 11 & p-Cymene & 1092 & 1.2 \\
\hline 12 & Limonene & 1094 & 2.3 \\
\hline 13 & 1,8-Cineol & 1098 & 21.0 \\
\hline 14 & cis-Ocimene & 1100 & 0.1 \\
\hline 15 & $\gamma$-Terpinene & 1116 & 0.2 \\
\hline 16 & cis-Sabinenehydrate & 1126 & 0.4 \\
\hline 17 & $\alpha$-Terpinolene & 1137 & 0.2 \\
\hline 18 & Linalool-L & 1148 & 0.2 \\
\hline 19 & Undecane & 1149 & 0.3 \\
\hline 20 & Camphor & 1185 & 19.1 \\
\hline 21 & Borneol-L & 1199 & 3.5 \\
\hline 22 & Terpinen - 4 -ol & 1205 & 0.9 \\
\hline 23 & Myrtenol & 1216 & 0.5 \\
\hline 24 & İsoborneol & 1222 & 0.1 \\
\hline 25 & Bornyl acetate & 1282 & 1.3 \\
\hline 26 & $\alpha$-Cubebene & 1337 & 0.2 \\
\hline 27 & $\alpha$-Ylangene & 1355 & 0.2 \\
\hline 28 & $\alpha$-Copaene & 1360 & 1.0 \\
\hline 29 & $\beta$-Bourbonene & 1366 & 0.1 \\
\hline 30 & $\alpha$-Copaene & 1369 & 0.1 \\
\hline 31 & cis-Jasmone & 1372 & 0.1 \\
\hline 32 & Cycloprop(e)azulene & 1383 & 0.2 \\
\hline 33 & $\beta$-Caryophyllene & 1393 & 1.0 \\
\hline 34 & $\beta$-Copaene & 1400 & 0.3 \\
\hline 35 & $\alpha$-Selinene & 1404 & 0.1 \\
\hline 36 & Aromadendrene & 1406 & 0.3 \\
\hline
\end{tabular}


Table 1. Constituents of the essential oil from S. crypthantha. (continue)

\begin{tabular}{|c|c|c|c|}
\hline 37 & 5,9-Undecadien & 1411 & 0.1 \\
\hline 38 & $\alpha$-Farnesene & 1415 & 0.1 \\
\hline 39 & $\alpha$-Humulene & 1418 & 1.5 \\
\hline 40 & apthalene & 1431 & 0.9 \\
\hline 41 & $\alpha$-Amorphene & 1434 & 0.1 \\
\hline 42 & Germacrene D & 1435 & 0.1 \\
\hline 43 & $\beta$-Selinene & 1441 & 0.4 \\
\hline 44 & ethyl-isoeugenol & 1442 & 0.8 \\
\hline 45 & icyclogermacrene & 1445 & 1.5 \\
\hline 46 & $\alpha$-Cadinene & 1458 & 0.2 \\
\hline 47 & Cis-Calamenene & 1461 & 0.2 \\
\hline 48 & Muurola-3,7-diene & 1468 & 0.2 \\
\hline 49 & $\alpha$-Calacorene & 1473 & 0.3 \\
\hline 50 & $\alpha$-Calacorene & 1486 & 0.1 \\
\hline 51 & 1,5-EpoxySalvial-4[14]-ene & 1490 & 0.7 \\
\hline 52 & Caryophyllenoxide & 1498 & 0.5 \\
\hline 53 & Gauaiol & 1500 & 0.1 \\
\hline 54 & Salvial-4[14]en-1-one & 1504 & 0.6 \\
\hline 55 & Muurolene & 1506 & 0.3 \\
\hline 56 & Jasmone & 1512 & 0.6 \\
\hline 57 & Isolongifolene & 1517 & 0.1 \\
\hline 58 & Germacrene B & 1524 & 0.4 \\
\hline 59 & $\alpha$-Cadinol & 1533 & 0.4 \\
\hline 60 & $\alpha$-Eudesmol & 1540 & 2.0 \\
\hline 61 & Valeranone & 1550 & 2.0 \\
\hline 62 & Ethanone & 1555 & 1.0 \\
\hline 63 & Abietane & 1756 & 0.1 \\
\hline & Total & & 98.7 \\
\hline
\end{tabular}

RRI: Relative Retention Index

sclaerol (6.6\%) ve spathulenol (4.1\%); $\alpha$-pinene (33.7\%), germacrene D (7.5\%), $\beta$-pinene $(6.8 \%)$, $\alpha$-humulene (6\%), veridiflorol (3.8\%) ve limonene (3.1\%) respectively [23]. Recently we have stated in a study, essential oils of the aerial parts of S. russellii and S. bracteata major constituents of S. russellii were thymol (31.9\%), $\alpha$-terpinol (13.1\%), $\gamma$-terpinene $(12.5 \%)$, whereas those $S$. bracteata were caryophyllene oxide $(17.8 \%) \alpha^{-}$ caryophyllene (16.7\%), $\beta$-pinene (10.5\%) [24].
In conclusion, our findings were generally similar to the literature results by the major components, because of minor differences from the research parameters. These variations may be due to the climatological factors, drying conditions, made of distillation and vary also qualitatively and/or quantitatively with collection period. These factors also play a role in the oil composition. This study demonstrates the 
occurrence of 1.8-cineole/camphor chemotype of S.cryptantha in eastern Anatolian region of Turkey.

\section{References}

1. B. Clebsch, C.D. Barner, The New Book of Salvias, Timber Pres, USA, p. 18. 2003.

2. G.P.P. Kamatou, N.P. Makunga, W.P.N. Ramogola, A.M. Viljoen, South African Salvia species: a review of biological activities and phytochemistry, J. Etnopharmacology, 119 (2008) 664-672.

3. A. Ipek, B. Gürbüz, M.Ü. Bingöl, F. Geven, G. Akgül, K. Afshar Pour Rezaeieh, B. Coşges, Comparison of essential oil components of wild and field grown Salvia cryptantha Montbert \& Aucher ex Benthan, in Turkey, Turk J. Agric. For., 36(2012) 668-672.

4. F. Celep, M. Doğan, A. Duran, A new record for the Flora of Turkey: Jacq (Labiatae), Turkish J. Botany, 33 (2009) 57-60.

5. P.H. Davis, Flora of Turkey and The East Aegean Island, Vol. 7, Edinburgh University Press, 1982.

6. Z. Saadia, M.M. Özcan, Y. Bagci, A. Ünver, D. Arslan, G. Durak, F. Er, C. Saglam, Chemical Composition of the Essential oil of Salvia cryptantha, JEOBP, 13 (2010) 200-204.

7. N. Perry, G. Court, Bidet, J. Court, E.K. Perry, Cholinergic activites of European herbs and potential of dementia therapy, J. Ger. Psy., 11 (1996) 1063-1069.

8. T. Baytop, Therapy with Medicinal Plants in Turkey (Past and Present). İstanbul University Publications No: 3255, Nobel Presshouse, İstanbul, 1999.

9. M. Tabata, E. Sezik, G. Honda, E. Yeşilada, H. Fukui, K. Goto, Y. Ikeshiro, Traditional medicine in Turkey. III. Folk medicine in East Anatolia, Van and Bitlis Provinces, Int. J. Pharmacognosy, 32 (1994) 3-12.

10. E. Yeşilada, G. Honda, E. Sezik, M. Tabata, T. Fujita, T. Tanaka, Y. Takeda, Y. Takaishi, Traditional medicine in Turkey. V. Folk medicine in the iner Taurus Mountains, J. Etnopharmacology, 46 (1995) 133-152.

11. G. Honda, E. Yeşilada, M. Tabata, E. Sezik, T. Fujita, Y. Takeda, Y. Takaishi, T. Tanaka, Traditional medicine in Turkey. VI. Folk medicine in West Anatolia: Afyon, Kütahya, Denizli, Muğla, Aydın provinces, J. Etnopharmacology, 53 (1996) 75-87.

12. E. Sezik, E. Yeşilada, M. Tabata, G. Honda, Y. Takaishi, F. Tetsuro, T. Tanaka, Y. Takeda, Traditional medicine in Turkey. VIII. Folk medicine in East Anatolia; Erzurum, Erzincan, Ağrı, Kars, Iğdır provinces, Economic Botany, 51 (1997) 195-211.
13. H. Ozer, A. Altun, S.U. Saraydın, S. Soylu, S. Goktas, E. Tuncer, D.S. Inan, B. Koksal, T.K. Temiz, B. Tepe, M. Şen, K. Karaday, M. Turan, Antitumoral effects of Salvia absconditiflora Greuter \& Burdet syn. Salvia cryptantha Montbret \& Aucher ex Benth. On Breast Cancer, 12 (2013) 390-397.

14. M. Lis- Balchin, S.G. Deans, Bioactivity of selected plant essential oils against Listeria monocytogenes, J. Appl. Bacteriol., 82 (1997) 759- 762.

15. J.E.F. Reynolds, Martindale- the extra pharmacopeia (31 st ed.). London: Royal Pharmaceutical Society of Great Britain, 1996.

16. B. Tepe, E. Dönmez, M. Unlu, F. Candan, D. Daferera, G. Vardar-Unlu, M. Polissiou, A. Somken, Antimicrobial and antioxidative activity of the essential oils and methanol extracts of Salvia cryptantha (Montbret et Aucher ex Benth.) and Salvia multicaulis (Vahl.), Food Chem., 84 (2004) 519-525.

17. K.H.C. Başer, S.H. Beis, T. Özek, Composition of the essential oil of Salvia cryptantha Montbret et Aucher ex Bent. from Turkey, J. Esent. Oil Res., 7 (1995) 113114.

18. A. Bayrak, A. Akgül, Composition of essential oils of Turkish Salvia species, Phytochem., 26 (1987) 846847.

19. A. Akgül, M. Özcan, F. Chialva, F. Monguzzi, Essential oils of four Turkish wild- growing Labiatae Herbs: Salvia crypthantha Montbr. Et Auch., Satureja cuneifolia Ten., Thymbra spicata L. and Thymus cilicicus Boiss. Et Bal., J. Essent. Oil Res., 11 (1999) 209-214.

20. A. Dogan, Studies on the essential oil of Salvia crypthantha Montbr. et Auch, Ankara Univ., Publ. No. 622, Ankara, Turkey, 1972

21. U. Bingol, B. Coşge, A. İpek, B. Gurbuz, F. Geven F, Identification of essential oil components of Salvia cryptantha Montbert \& Aucher ex Benthan, growing wild in Turkey, Asian J. Chem., 21 (2009) 3836-3840.

22. E. Bağ Cl, A. Koçak, Essential oil composition of two Salvia L. (S. multicaulis Vahl. Enum. and S. trichoclada Bentham) species from East Anatolian Region (Turkey), Int. J. Sci. Tech., 3 (2008a) 13-18.

23. E. Bağcl, A. Koçak, Salvia palaestina Bentham S. tomentosa Miller türlerinin uçucu yağ kompozisyonu, kemotaksonomik bir yaklaşım, Fırat Üniversitesi Fen ve Mühendislik Bilimleri Dergisi, 20 (2008) 35-41.

24. G. Dogan, A. Demirpolat, E. Bagci, Essential oil composition of aerial parts of two Salvia L. (S. russellii Bentham and S. bracteata Banks and Sol.) species, Asian J. Chem., 26 (2014) 5998-6000. 